\title{
DYNAMIC PROBABILITY OF THE INDONESIAN ARCHIPELAGO UNDERWATER DEFENCE WITH SUBMARINE SONAR
}

\author{
Avando Bastari ${ }^{1}$, Benny Sukandari ${ }^{2}$, Joni Widjayanto ${ }^{3}$, Dani Hutabarat 4 \\ ${ }^{1,4}$ Indonesia Naval Technology College, STTAL Surabaya Indonesia \\ ${ }^{2}$ Indonesia Naval Command and Staff College, Seskoal Jakarta Indonesia \\ ${ }^{3}$ Indonesia Defense University, Unhan Jakarta Indonesia
}

\begin{abstract}
This paper study the determination of the number submarine defenses for Indonesian archipelago underwater defenses with probability method approach. In performing these calculations the authors perform the processing of data from various sources, both from the literature, the data from the relevant authorities in this regard Operations staff, Submarine Force with the elements in the form of operating reports, obtained through interviews and from the field. From these data processed probability calculation and the result obtained is inserted into the formula length / width of the waiting area submarine patrol positions further implemented method of calculating the probability to obtain optimal results. The result of this study is to know the total number of submarines are needed to maintain the strategic straits Indonesia as much as 13 submarines. With the percentage of each strategic submarines: 23\% Makassar Strait (3 Submarines), the Lombok Strait 15.4\% (2 Submarines), Strait of Halmahera 30.77\% (4 Submarines), Wetar Strait 15.4\% (2 Submarines), Strait Ombai 15.4\% (2 Submarines). If there is a dynamic field that can easily be placed in the strait Submarines received threats in accordance with the percentage division. Suppose a threat occurs only in Hot Area I (Makassar Strait and the Strait of Lombok) then placed Submarines strength at 35.4\% (5 Submarines).
\end{abstract}

Keywords: Submarine, Probability Concepts, Determination of Total submarine

\section{INTRODUCTION}

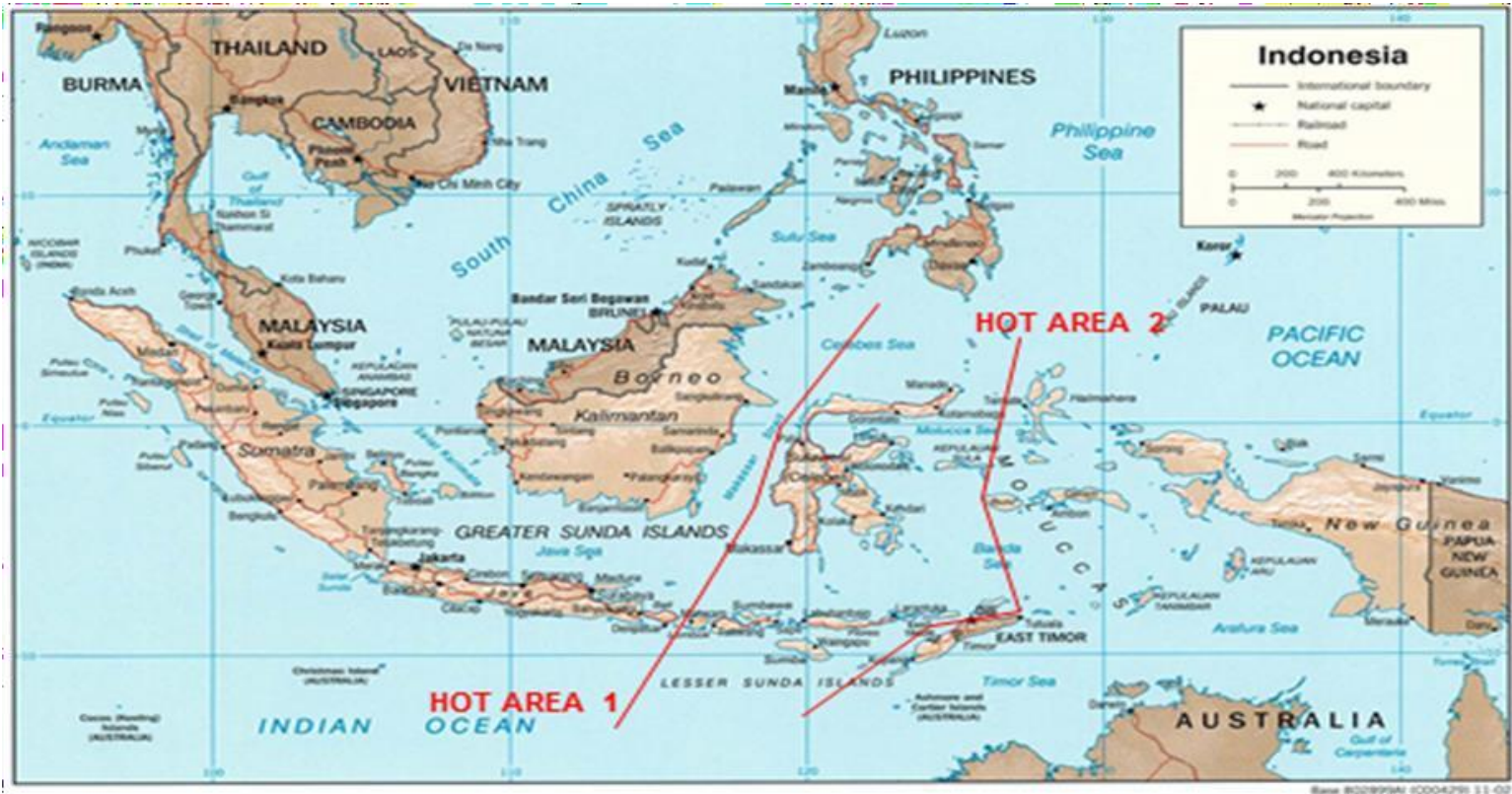

Fig.1 Hot Area Map

Indonesian waters consist of two types of waters, namely shallow waters and ocean waters. In the power development Indonesian Navy blue print of the 2005-2024 it was stated that for shallow waters a medium mining strategy and for deep waters was carried out with a submarine defense pattern (Long Term Indonesian Navy Strength Development Plan, 2005-2024).

In the deep defense system, there are two areas that have a very high level of vulnerability to the threat of invasion as shown in figure 1.1 Hot area 1 is in the Sulawesi Sea and Makassar Strait, 
while Hot area 2 is in the Timor Sea, Banda Sea, Aru Sea, Ombai Strait and Wetar Strait.

In this paper we will look for a probability detection approach from submarine sensor equipment that is used as a basis for determining the number of submarines operating in each strategic strait.

This paper used some kinds of literature to support the research:

a. Research Review, for example paper titled Determining the number of submarines based on the width of the strait divided by the width of the waiting position (Muhammad Ali, 2002), This study ignores the probability of detection but is sufficient as an initial comparison. Determining the number of submarines based on the Combat manual book of battle formula. This method does not pay attention to the probability of detection and assessment of the initial threat as a variable in determining the number of submarines is very subjective which should contain an element of objectivity (Antongan Simatupang, 2003).

\section{b. Probability Concepts}

The success of detecting and searching for a target in the sea can be achieved if the probability can be calculated. Ideally the probability of successfully detecting and finding targets is obtained if the probability numbers obtained are close to 1 (one).

c. Detection and Search Theory

1) Determinants of detection
a) kind of target
b) surrounding sea conditions
c) conditions of sensor equipment
d) methods / tactics used

2) Lateral distance

The target will pass following a straight line through or bypassing the detection and sensor possible zones. The closest distance measured from the detection vessel to the target which is the closest approach point is defined as the lateral distance and given the symbol $x$. While the probable detection area inside the circle of the detection device has a radius which is the maximum possible detection distance, given the $\mathrm{Rm}$ notation. The graphical presentation of the target movement situation is shown in Figure 1.2 (Naval Operation Analysis Ch 6 p. 111, 1999).

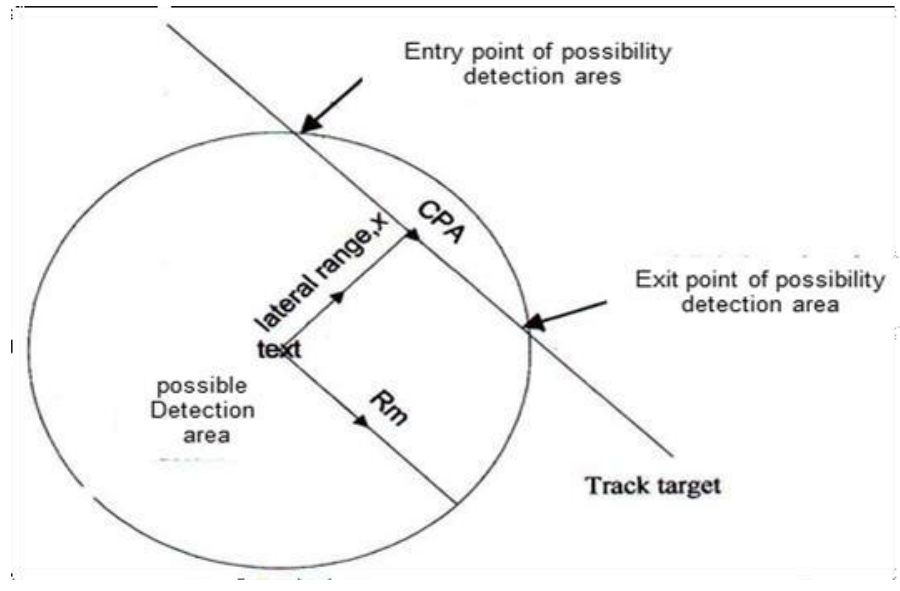

Fig.2 Lateral distance where:

CPA : Clossest Point Approach, that is the closest meeting point between target with a detection vessel
$\mathrm{Rm}$ : radius range of the sensor of the detection vessel

$x \quad$ : lateral distance 
The probability of detecting an incoming target and cutting the detection zone and detection equipment sensor at lateral $x$ distance is calculating the cumulative probability $P(x)$, where the cumulative probability $P(x)$ is defined as the cumulation and probability of detecting the target when the target enters the detection zone until the target exits detection zone.

The cumulative probability of $P(x)$ can be graphically represented as a curve called the lateral distance curve as shown in the figure 1.3 (Naval Operation Analysis Ch 6 hal 112, 1999).

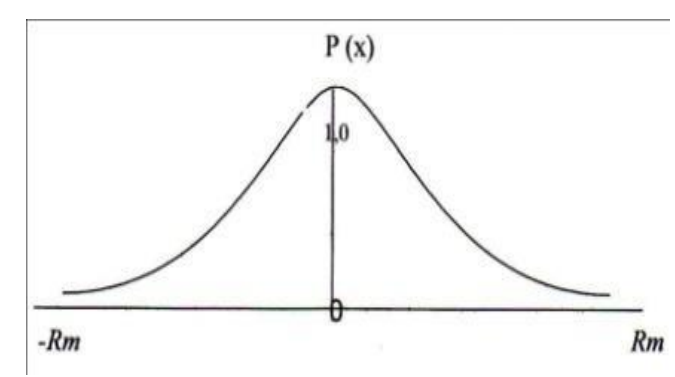

Fig.3 Lateral Distance Curve

4) Sweeping width (W)

W physically shows the effective width of the detection zone from the sensors of our ship's detection equipment. Sweeping width (W) is a measure of the ability of a detection device, so it is also a measure of the probability of detection (Naval Operation Analysis Ch 6 p. 118, 1999).

Formula $\mathrm{W}$ is:

$$
W=\int_{-R m}^{R m} P(x) d x
$$

\section{Random Search Method}

I A target is in a certain sea area with area A, because of lack of information, then the target position is considered to be randomly distributed. A is divided into $\mathrm{N}$ equal parts. For example the target can be detected in one part and $A$ where the opportunity to detect this is the same as if the target is in another part. Suppose the observer searches in this area $A$ without using a systematic plan or method.
When detection is done in the first part, two detections occur. Suppose $B$ is a situation that targets in an area with a length and width of $2 \mathrm{Rm}$, so that there is a chance of detection and assuming $C$ is a situation that targets are detected, then

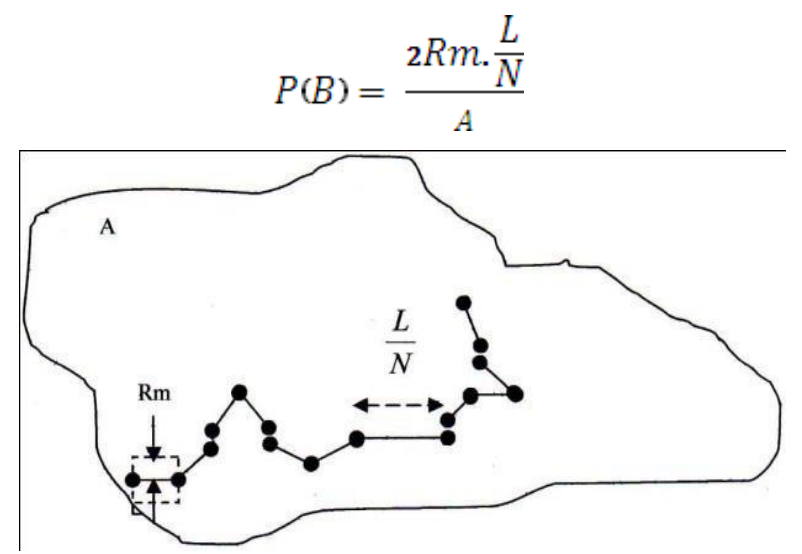

Fig.4 Random Search

From Eq $P\left(\frac{C}{B}\right)=\frac{1}{2 R m} \int_{-R m}^{R m} P(x) d x$

$\mathrm{P}($ detection $)=\mathrm{P}(\mathrm{C} / \mathrm{B}) \cdot \mathrm{P}(\mathrm{B})$

$$
=\frac{2 R m \cdot \frac{\bar{N}}{A}}{2 R m} \int_{-R m}^{\pi m s} P(x) d x
$$

For detection in the first part:

$$
\begin{aligned}
& =\frac{L}{N A} \int_{-R m}^{R m} P(x) d x \\
& =\frac{W L}{N A}
\end{aligned}
$$

So in general, for the $\mathrm{i}, \mathrm{P}$ search section (detection occurs in the $\mathrm{i} / \mathrm{no}$ detection section) $\geq$ $\frac{W L}{N A}$

While in the remaining area (parts of the sea in area $A$ except the first area where the area is $\leq A$, which may also be the target location), there is no detection.

$P$ (unsuccessful detection in part i /

undetection) $\leq 1-\frac{W L}{N A}$ 
So $\left(1-\frac{W L}{N A}\right)$ is the upper limit (maximum price) and the probability of detecting in part i. By using a chain rule of conditional probability, the upper limit of the probability of failing to detect for a search is:

$\mathrm{P}($ undetection $)=\prod_{i=1}^{N}\left(1-\frac{W L}{N A}\right)=\left(1-\frac{W L}{N A}\right)^{N}$

The lower limit (the smallest price) of a probability is detected:

$\mathrm{P}($ dettection $)=1-\left(1-\frac{W L}{N A}\right)^{N}$ for all searches

For $\frac{W L}{N A}$ small then in $\left(1-\frac{W L}{N A}\right) \cong-\frac{W L}{N A}$ so that:

$\left(1-\frac{W L}{N A}\right)^{W}=e^{N \operatorname{In}\left(1-\frac{W L}{N A}\right)}=e^{-\frac{W L}{A}}$

So that the lower limit (the smallest price) of the probability of detection in a random search model (Naval Operation Analysis Ch 7 p. 125, 1999) is:

$\mathrm{P}($ detection $)=1-\left(1-\frac{W L}{N A}\right)^{N} 1-e^{N \ln \left(1-\frac{W L}{N A}\right)}$

$$
=1-e^{N \operatorname{In}\left(1-\frac{W L}{N A}\right)}
$$

$\mathrm{P}($ detection $)=1-e^{-\frac{W L}{A}}$

$\mathrm{W}$ = wide

$\mathrm{L} \quad=$ patrol track length

A = the area of the sea where the enemy is estimated to be

\section{Submarine preventive method}

There are several kinds of preventive methods by submarines carried out by the Navy (Cakra Class Submarine Ship Type Combat manual book, 1988), including:
a. Position Method
b. Manuvra position method
c. Free Hunting Method
d. Wolf Pack Method

\section{Area Size Waiting for Submarines}

Based on the Chakra class Tactical User Guide for Submarine Combat Use, then graphically the length of the submarine waiting area size patrol position method is in figure 1.5

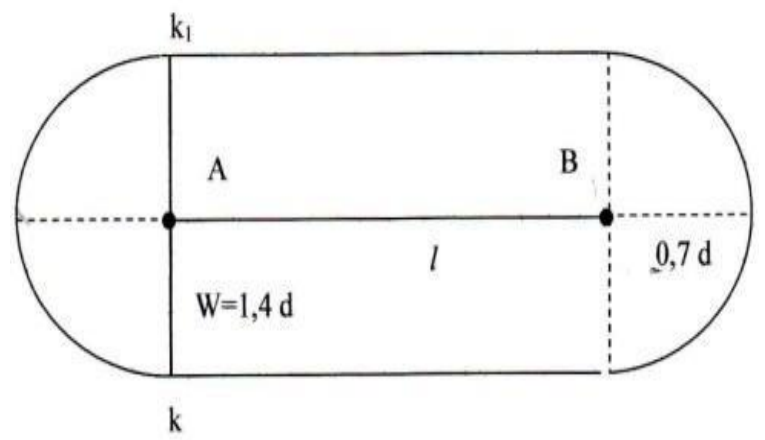

Fig.5 Length / width size of submarine waiting area patrol position method

Formula:

$\mathrm{W} \quad=1,4 \mathrm{~d}$

$\mathrm{L} \quad=1,4 \mathrm{~d} \times\left(\frac{V s}{2 V m}+1\right)$ sehingga

$\mathrm{L}=\left[1,4 d x\left(\frac{V s}{2 V m}+1\right)+1,4 d\right]$

Line $A B=1,4 d \frac{V s}{2 V k}$

then the length of the waiting location sector $=0,7 \mathrm{~d}$ $+\mathrm{L}+0,7 \mathrm{~d}$

$=1,4 \mathrm{~d}+1,4 \mathrm{~d} \frac{V s}{2 V k} \quad=1,4 \mathrm{~d}\left(1+\frac{V s}{2 V m}\right)$

Where :

$$
\begin{array}{ll}
\mathrm{W} & =\text { width of the waiting location sector } \\
\mathrm{d} & =\text { passive sonar detection distance } \\
\mathrm{L} & =\text { patrol line length (pacing) } \\
\mathrm{Vs} & =\text { fast detection submarine } \\
\mathrm{Vm} & =\text { fast opponent }
\end{array}
$$

\section{MATERIALS/METHODOLOGY}

\subsection{Stage of Research}

a. Identification of problems. The research begins with the identification of problems. If the state of the country is in a state of war and faces 
the threat of foreign military forces, then the Navy as part of the element of enforcing the sovereignty of the state must ensure that its sea territory remains under control (sea control).

b. Objectives and Benefits of Research. Determine the number of $\mathrm{KS}$ needed in strategic straits to find the best solution by applying the target detection probability method.

c. Observation and Consultation. Implemented at the Koarmatim Operations Staff and the Koarmatim Submarine Unit.

d. Library Studies and Preliminary Studies. For data processing, literature studies are conducted on Search and Detection Theory. e. Data Collection. The width of the strait was observed, the length of submarine patrol tracks in the funnel area, the interception method chosen and the width of the submarine sonar sweep.

f. Data processing. Implemented by calculating the probability of each scenario in each strait.

g. Interpretation Analysis of the results of Data Processing Results.

h. Conclusions and Suggestions. Research that can be taken into consideration in the procurement of the Navy Navy for the enforcement of sovereignty in Indonesian waters.

\subsection{Research Flow Chart}

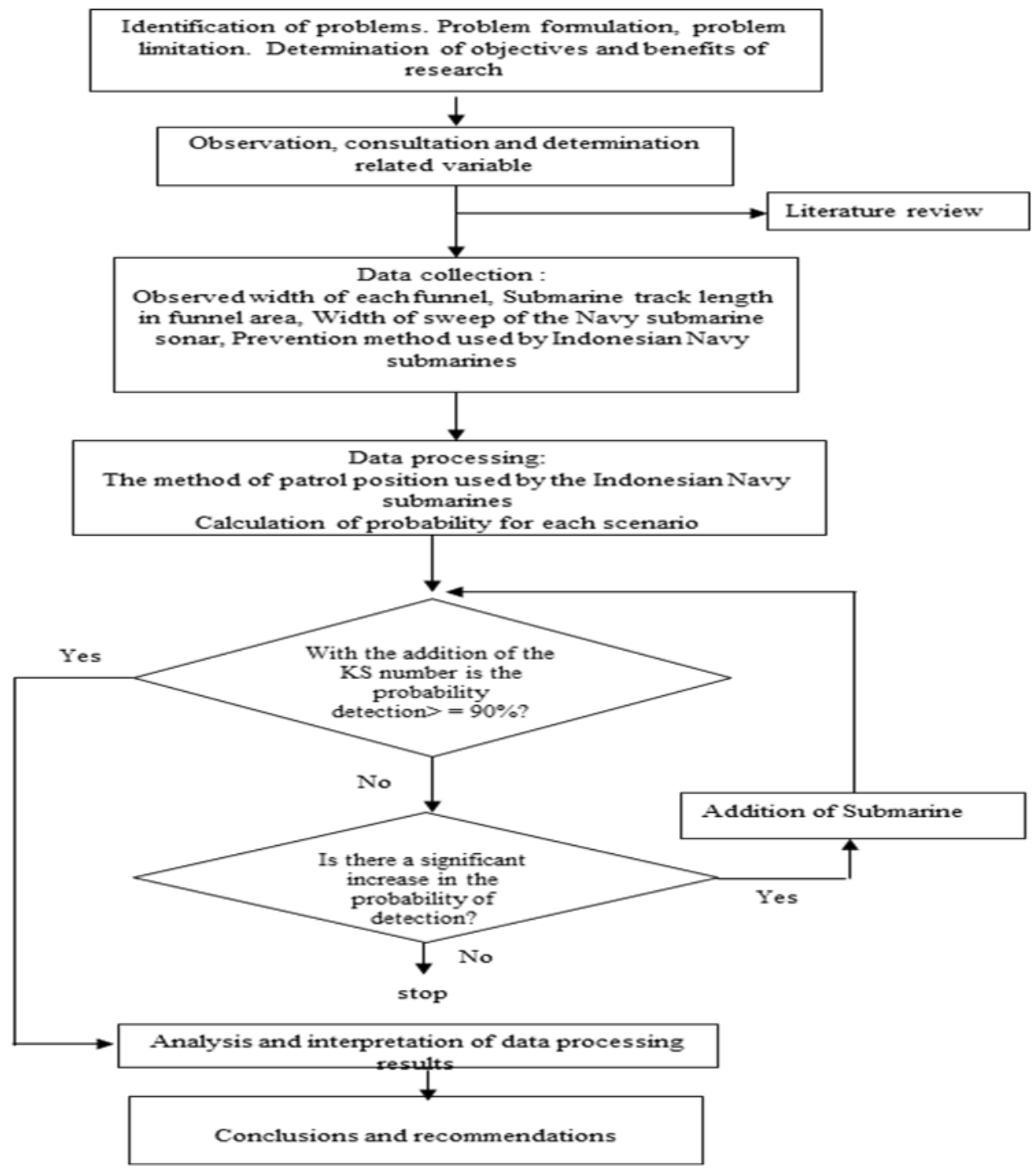

Fig.6 Research Flow Chart 
3. RESULT AND DISCUSSION.

a. Data collection

1) Seabed Waters of Indonesia

2) Geography of Indonesian Waters

3) Seabed Profile

4) Potential Areas of Submarine Interception

Operations.

5) Types of Submarines owned by the Navy

The 209/1300 submarines are 2 German submarines purchased by the Indonesian government, namely KRI Cakra (401) and KRI Nanggala (402).

6) Submarine Sonar type

According to the type of sonar there are two:

(a) Active Sonar

Sonar planes that can emit sound waves (acoustic waves) to targets or objects that are below the surface of the water / in the sea.

Table 1. Active Sonar types

\begin{tabular}{|c|c|c|c|c|c|}
\hline \multicolumn{6}{|c|}{ Active Sonar Types } \\
\hline Sonar Type & Purpose & Frequency & Range & Platform & Array Type \\
\hline ASW & $\begin{array}{l}\text { Active Detection: } \\
\text {-Submarine } \\
\text {-Surface vessel } \\
\text {-Range, Bearing, Doppler }\end{array}$ & $\begin{array}{l}\text { LF: }<2 \mathrm{kHz} \\
M F: 2 \mathrm{kHz}-10 \mathrm{kHz} \\
\mathrm{HF}:>10 \mathrm{kHz}\end{array}$ & $29 \mathrm{~km}$ & $\begin{array}{l}\text { - Frigates, DDG } \\
\text { - Submarine } \\
\text { - Helicopter }\end{array}$ & $\begin{array}{l}\text { - Cylindrical Bow } \\
\text { - Towed Array } \\
\text { - Dipping Array }\end{array}$ \\
\hline Mine Avoidance & $\begin{array}{l}\text { Active Detection: } \\
\text {-Mines } \\
\text {-Obstacles } \\
\text {-Range, Bearing, Autodetection }\end{array}$ & $30 \mathrm{kHz}-70 \mathrm{kHz}$ & $0,9 \mathrm{~km}$ & $\begin{array}{l}\text { - Surface Vessel } \\
\text { - Submarine }\end{array}$ & $\begin{array}{l}\text { - Planar Bow } \\
\text { - Mills-Cross Bow }\end{array}$ \\
\hline Mine Hunting & $\begin{array}{l}\text { Active Imaging Sonar: } \\
\text {-Buried, moored, surface } \\
\text { mines }\end{array}$ & $100 \mathrm{kHz}-500 \mathrm{kHz}$ & $50-100 m$ & $\begin{array}{l}\text { - Surface Vessel } \\
\text {-AUV, ROV }\end{array}$ & - Mills Cross \\
\hline Echo Sounder & $\begin{array}{l}\text { Active Detection: } \\
\text {-Depth } \\
\text {-Water Column Imaging }\end{array}$ & $12 \mathrm{kHz}-1 \mathrm{MHz}$ & $0.1-12 \mathrm{~km}$ & $\begin{array}{l}\text { - Surface Vessel } \\
\text { - Submarine }\end{array}$ & - Transducer Hull \\
\hline UT & $\begin{array}{l}\text { Underwater Communication: } \\
\text {-Voice } \\
\text {-Data }\end{array}$ & $1 \mathrm{kHz}-60 \mathrm{kHz}$ & $1-32 \mathrm{~km}$ & $\begin{array}{l}\text { - Surface Vessel } \\
\text { - Submarine }\end{array}$ & - Transducer Hull \\
\hline
\end{tabular}

\section{(b) Passive Sonar}

That is, sonar planes that can targets or objects that cause sound (sonic).

only receive acoustic waves emitted by

Tabel 2. Passive Sonar types

\section{Passive Sonar Types}

\begin{tabular}{|c|c|c|c|c|c|}
\hline Sonar Type & Purpose & Frequency & Range & Platform & Array Type \\
\hline Passive Bow & $\begin{array}{l}\text { Passive Detection: } \\
\text { - Submarine } \\
\text { - Surface Vessel } \\
\text { - Bearing, Audio, DEMON }\end{array}$ & $\begin{array}{c}0.3 \mathrm{kHz}-12 \\
\mathrm{kHz}\end{array}$ & $32 \mathrm{~km}$ & Submarine & $\begin{array}{l}\text { - Cylindrical Bow } \\
\text { - Conformal Bow }\end{array}$ \\
\hline Intercept & $\begin{array}{l}\text { Passive Detection: } \\
\text { - Active sonar pulses } \\
\text { - ASW, Torpedo Sonar } \\
\text { - Bearing, Range, Pulse analysis }\end{array}$ & $1 \mathrm{kHz}-500 \mathrm{kHz}$ & $32 \mathrm{~km}$ & Submarine & - Cylindrical \\
\hline Passive Ranging & $\begin{array}{l}\text { Passive Detection + ROC: } \\
\text { - Submarine } \\
\text { - Surface Vessel } \\
\text { - Bearing, Range }\end{array}$ & $1.8 \mathrm{kHz}-8 \mathrm{kHz}$ & $16 \mathrm{~km}$ & Submarine & - Planar Distributed \\
\hline Flank Array & $\begin{array}{l}\text { Long range passive detection: } \\
\text { - Submarine } \\
\text { - Surface Vessel } \\
\text { - Bearing, Audio, LOFAR }\end{array}$ & $10 \mathrm{~Hz}-1 \mathrm{kHz}$ & $64 \mathrm{~km}$ & Submarine & - Line, Planar \\
\hline
\end{tabular}


Chakra Class Submarines Type 209/1300 uses passive Sonar PRS 3 (Passive Ranging Sonar 3) which functions as detection (ships on water, submarines and torpedoes), transfers data to the FCE (Fire Control Equipment) and analyzes sound propagation in water .

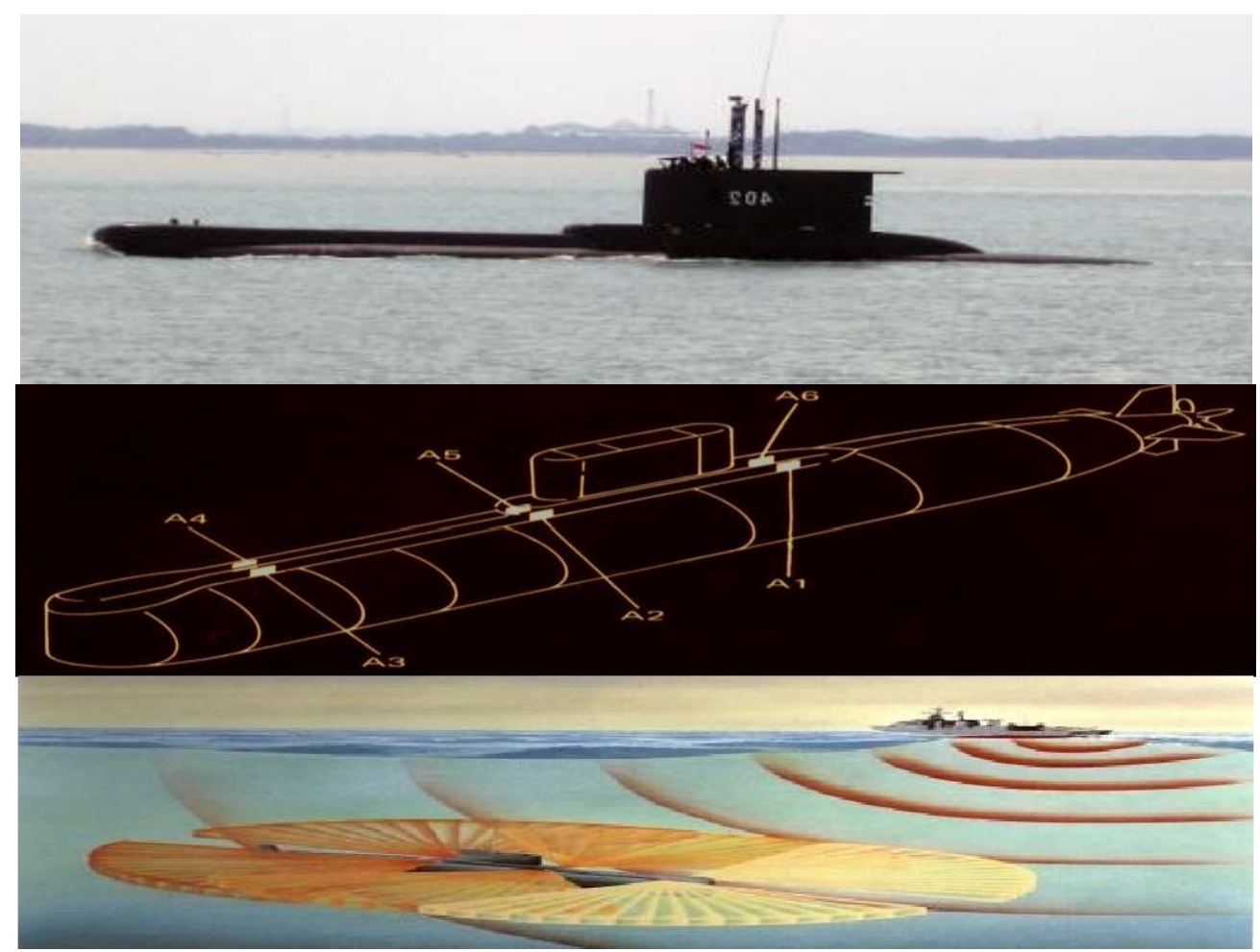

Fig.7 PRS 3 Sonar Placement

But there are also sonar equipment that have dual functions, which can be active or passive sonar. Examples of passive active sonar types include: MDA (Mine Detection Avoidance), Bow Array, CSU (Compact Sonar U-Boote). On Type 209/1300 Submarines the Chakra Class uses a passive active Sonar type CSU 3 which has a sonar range of $20 \mathrm{Nm}$ in diameter. b. Data processing

1) Potential Areas of Submarine Interception Operations.

Based on the book "The Concept of Marine Guerilla Warfare Class 209/1300" (Muhammad Ali, 2003), the submarine interception operation area is determined in table 3.3. as follows :

Table 3. Areas of Submarine Interception Operations

\begin{tabular}{|c|c|c|c|}
\hline Name Location & Size / Coordinate & Seabed / Depth & Description \\
\hline $\begin{array}{l}\text { Makassar Strait } \\
\text { (Sea map No: 139) }\end{array}$ & $\begin{array}{l}\mathrm{P}=38 \mathrm{Nm} \\
\mathrm{l}=28 \mathrm{Nm} \\
\mathrm{L}=1624 \mathrm{Nm}^{2} \\
00^{0} 42^{\prime} 00^{\prime \prime} \mathrm{U}-118^{0} 57^{\prime} 30^{\prime \prime} \mathrm{T} \\
01^{0} 04^{\prime} 30^{\prime \prime} \mathrm{U}-119^{\circ} 05^{\prime} 30^{\prime \prime} \mathrm{T} \\
00^{\circ} 48^{\prime} 30^{\prime \prime} \mathrm{U}-19^{0} 53^{\prime} 00^{\prime \prime} \mathrm{T} \\
00^{0} 25^{\prime} 00^{\prime \prime} \mathrm{U}-119^{0} 43^{\prime} 30^{\prime \prime T}\end{array}$ & $\begin{array}{l}\text { C type } \\
\text { Depth } 40 \text { s / d2000m } \\
\text { Sand bottom } \\
\text { Flow to southwest and } \\
\text { south or vice versa } \\
\text { Current velocity } 2 \text { Knots }\end{array}$ & $\begin{array}{l}\text { North Season in January to } \\
\text { June } \\
2-3 m \text { waves } \\
\text { South season in December } \\
\text { The sea is relatively calm }\end{array}$ \\
\hline $\begin{array}{l}\text { Lombok Strait } \\
\text { (Sea map No: 291) }\end{array}$ & $\begin{array}{l}P=20 \mathrm{Nm} \\
\mathrm{I}=28 \mathrm{Nm} \\
\mathrm{L}=560 \mathrm{Nm}^{2} \\
08^{0} 15^{\prime} 00^{\prime \prime} \mathrm{S}-115^{0} 45^{\prime} 30^{\prime \prime} \mathrm{T} \\
08^{0} 18^{\prime} 00^{\prime \prime} \mathrm{S}-116^{0} 01^{\prime} 30^{\prime \prime} \mathrm{T} \\
08^{0} 34^{\prime} 00^{\prime \prime} \mathrm{S}-115^{0} 58^{\prime} 30^{\prime \prime} \mathrm{T} \\
08^{0} 31^{\prime} 00^{\prime \prime} \mathrm{S}-115^{0} 42^{\prime} 30^{\prime \prime} \mathrm{T}\end{array}$ & $\begin{array}{l}\text { B and C type } \\
\text { Depth } 200 \text { s / d2000m } \\
\text { The basis of sand and stone } \\
\text { The east to north season } \\
\text { currents and the west to } \\
\text { south season currents } \\
\text { The current speed of } 6 \\
\text { Knots }\end{array}$ & $\begin{array}{l}\text { Ocean waves adjusts the } \\
\text { Indonesian oceanic square }\end{array}$ \\
\hline
\end{tabular}




\begin{tabular}{|c|c|c|c|}
\hline Name Location & Size / Coordinate & Seabed / Depth & Description \\
\hline $\begin{array}{l}\text { Sea of Halmahera } \\
\text { (Sea map No: } 357 \text { ) }\end{array}$ & 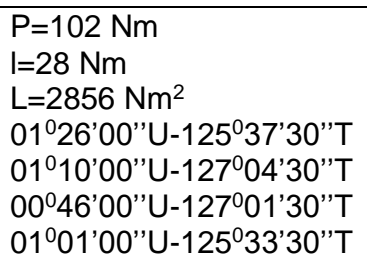 & $\begin{array}{l}\text { D type } \\
\text { Depth } 60 \text { s / d } 4000 \mathrm{~m} \\
\text { The basis of sand and stone } \\
\text { Current to the southwest } \\
\text { and southeast or vice versa } \\
\text { Current speed of } 4 \text { Knots }\end{array}$ & $\begin{array}{l}\text { Sea waves in the northern } \\
\text { season between January to } \\
\text { June } 2-3 m \\
\text { In the southern season from } \\
\text { July to December it is } \\
\text { relatively quiet }\end{array}$ \\
\hline $\begin{array}{l}\text { Wetar Strait } \\
\text { (Sea Map No: 378) }\end{array}$ & 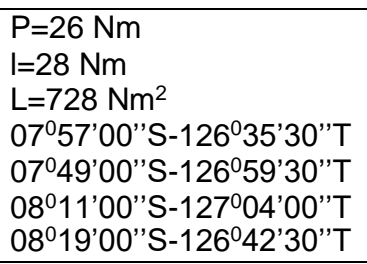 & $\begin{array}{l}\text { D type } \\
\text { Depth of } 50 \mathrm{~s} / \mathrm{d} 5000 \mathrm{~m} \\
\text { Basic coral and rock } \\
\text { Flow to the Banda Sea and } \\
\text { vice versa } \\
\text { Current speed of } 4 \text { Knots }\end{array}$ & $\begin{array}{l}\text { Ocean waves adjust the } \\
\text { Banda sea square }\end{array}$ \\
\hline $\begin{array}{l}\text { Ombai Strait } \\
\text { (Sea map No: 376) }\end{array}$ & 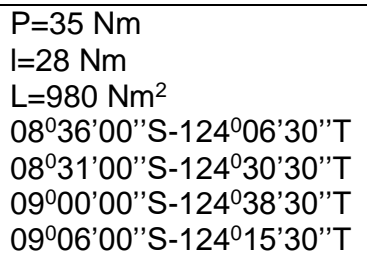 & $\begin{array}{l}\text { D type } \\
\text { Depth of } 46 \text { s / d3800m } \\
\text { Basic coral and rock } \\
\text { Flow towards Sawu sea } \\
\text { and vice versa } \\
\text { The current speed of 6-7 } \\
\text { Knots }\end{array}$ & $\begin{array}{l}\text { ocean waves adjusts the } \\
\text { Indonesian oceanic square }\end{array}$ \\
\hline
\end{tabular}

2) Determine the probability of submarine detection

$\mathrm{P}($ detection $)=1-\mathrm{e}^{-\mathrm{WL} / \mathrm{A}}$

3) W (submarine wide sweeping sonar) using the patrol position method is obtained by determining the length of the waiting position.

Data Processing of Submarine Interception Areas

If the speed of the submarine itself $(V s)=8$ knot
And the speed of the enemy ship $(\mathrm{Vm})=$ 15 knot

$$
\begin{aligned}
\mathrm{W} & =1,4 d=1,4 \cdot 20=28 \mathrm{Nm} \\
\mathrm{L} & =1,4 d+1,4 d \frac{\mathrm{Vs}}{2 \mathrm{Vk}} \\
& =28+28 \frac{8}{2 \times 15} \\
& =35,466 \mathrm{Nm}
\end{aligned}
$$

So the probability of submarine detection (KS) on each strait using the patrol position method is as follows:

\section{a) Makassar Strait}

Tabel 4. Probability submarine detection table at Makassar Strait

\begin{tabular}{|c|c|c|c|c|c|c|c|c|c|c|}
\hline w & L & A & $\mathbf{W}^{\star} \mathrm{L}$ & $W^{*} L / A$ & $(-) W^{*} \mathrm{~L} / \mathrm{A}$ & e & $e^{\wedge}(-) W^{\star} L / A$ & $f$ & $f-e^{\wedge}(-) W^{*} L / A$ & $(b+f)-b$ \\
\hline 28 & 35,466 & 560 & 993,048 & 1,773 & $-1,773$ & 2,718 & 0,170 & 1 & 0,830 & \\
\hline 28 & 35,466 & 280 & 993,048 & 3,547 & $-3,547$ & 2,718 & 0,029 & 1 & 0,971 & 0,141 \\
\hline 28 & 35,466 & 186,667 & 993,048 & 5,320 & $-5,320$ & 2,718 & 0,005 & 1 & 0,995 & 0,024 \\
\hline
\end{tabular}

\begin{tabular}{|c|c|c|c|c|c|c|c|c|c|c|}
\hline $\mathbf{W}$ & $\mathbf{L}$ & $\mathbf{A}$ & $\mathbf{\mathbf { W } ^ { * } \mathbf { L }}$ & $\mathbf{W}^{*} \mathbf{L} / \mathbf{A}$ & $\mathbf{( - ) \mathbf { W } ^ { * } \mathbf { L } / \mathbf { A }}$ & $\mathbf{e}$ & $\mathbf{e}^{\wedge}(-) \mathbf{W}^{*} \mathbf{L} / \mathbf{A}$ & $\mathbf{f}$ & $\mathbf{f - e} \mathbf{e}^{\wedge}(-) \mathbf{W}^{*} \mathbf{L} / \mathbf{A}$ & $\mathbf{( b + f ) - \mathbf { b }}$ \\
\hline 28 & 35,466 & 1624 & 993,048 & 0,611 & $-0,611$ & 2,718 & 0,543 & 1 & 0,457 & \\
\hline 28 & 35,466 & 812 & 993,048 & 1,223 & $-1,223$ & 2,718 & 0,294 & 1 & 0,706 & 0,248 \\
\hline 28 & 35,466 & 541,333 & 993,048 & 1,834 & $-1,834$ & 2,718 & 0,160 & 1 & 0,840 & 0,135 \\
\hline 28 & 35,466 & 406 & 993,048 & 2,446 & $-2,446$ & 2,718 & 0,087 & 1 & 0,913 & 0,073 \\
\hline
\end{tabular}

b) Lombok Strait

Tabel 5. Probability submarine detection table at Lombok Strait 
Tabel 6. Probability submarine detection table at Halmahera Sea

\begin{tabular}{|c|c|c|c|c|c|c|c|c|c|c|}
\hline w & L & A & $W^{*} \mathbf{L}$ & $W^{*} L / A$ & $(-) W^{*} L / A$ & e & $e^{\wedge}(-) W^{\star} L / A$ & $f$ & $f-e^{\wedge}(-) W^{*} L / A$ & $(b+f)-b$ \\
\hline 28 & 35,466 & 2856 & 993,048 & 0,348 & $-0,348$ & 2,718 & 0,706 & 1 & 0,294 & \\
\hline 28 & 35,466 & 1428 & 993,048 & 0,695 & $-0,695$ & 2,718 & 0,499 & 1 & 0,501 & 0,207 \\
\hline 28 & 35,466 & 952 & 993,048 & 1,043 & $-1,043$ & 2,718 & 0,352 & 1 & 0,648 & 0,147 \\
\hline 28 & 35,466 & 714 & 993,048 & 1,391 & $-1,391$ & 2,718 & 0,249 & 1 & 0,751 & 0,103 \\
\hline 28 & 35,466 & 571,2 & 993,048 & 1,739 & $-1,739$ & 2,718 & 0,176 & 1 & 0,824 & 0,073 \\
\hline
\end{tabular}

d) Wetar Strait

Tabel 7. Probability submarine detection table at Wetar Strait

\begin{tabular}{|c|c|c|c|c|c|c|c|c|c|c|}
\hline $\mathbf{W}$ & $\mathbf{L}$ & $\mathbf{A}$ & $\mathbf{W}^{\star} \mathbf{L}$ & $\mathbf{W}^{\star} \mathbf{L} / \mathbf{A}$ & $\mathbf{( - )} \mathbf{W}^{\star} \mathbf{L} / \mathbf{A}$ & $\mathbf{e}$ & $\mathbf{e}^{\wedge}(-) \mathbf{W}^{\star} \mathbf{L} / \mathbf{A}$ & $\mathbf{f}$ & $\mathbf{f - e} \mathbf{e}^{\wedge}(-) \mathbf{W}^{\star} \mathbf{L} / \mathbf{A}$ & $\mathbf{( b + f ) - b}$ \\
\hline 28 & 35,466 & 728 & 993,048 & 1,364 & $-1,364$ & 2,718 & 0,256 & 1 & 0,744 & \\
\hline 28 & 35,466 & 364 & 993,048 & 2,728 & $-2,728$ & 2,718 & 0,065 & 1 & 0,935 & 0,190 \\
\hline 28 & 35,466 & 242,667 & 993,048 & 4,092 & $-4,092$ & 2,718 & 0,017 & 1 & 0,983 & 0,049 \\
\hline
\end{tabular}

e) Ombai Strait

Tabel.8. Probability submarine detection table at Ombai Strait

\begin{tabular}{|c|c|c|c|c|c|c|c|c|c|c|}
\hline $\mathbf{W}$ & $\mathbf{L}$ & $\mathbf{A}$ & $\mathbf{\mathbf { W } ^ { * } \mathbf { L }}$ & $\mathbf{W}^{*} \mathbf{L} / \mathbf{A}$ & $\mathbf{( - ) \mathbf { W } ^ { * } \mathbf { L } / \mathbf { A }}$ & $\mathbf{e}$ & $\mathbf{e}^{\wedge}(-) \mathbf{W}^{*} \mathbf{L} / \mathbf{A}$ & $\mathbf{f}$ & $\mathbf{f - \mathbf { e } ^ { \wedge } ( - ) \mathbf { W } \mathbf { W } ^ { * } \mathbf { L } / \mathbf { A }}$ & $\mathbf{( b + \mathbf { f } ) - \mathbf { b }}$ \\
\hline 28 & 35,466 & 980 & 993,048 & 1,013 & $-1,013$ & 2,718 & 0,363 & 1 & 0,637 & \\
\hline 28 & 35,466 & 490 & 993,048 & 2,027 & $-2,027$ & 2,718 & 0,132 & 1 & 0,868 & 0,231 \\
\hline 28 & 35,466 & 326,667 & 993,048 & 3,040 & $-3,040$ & 2,718 & 0,048 & 1 & 0,952 & 0,084 \\
\hline
\end{tabular}

Based on data obtained from the probability included in the probability graph as follows: table the submarine detection of each strait is

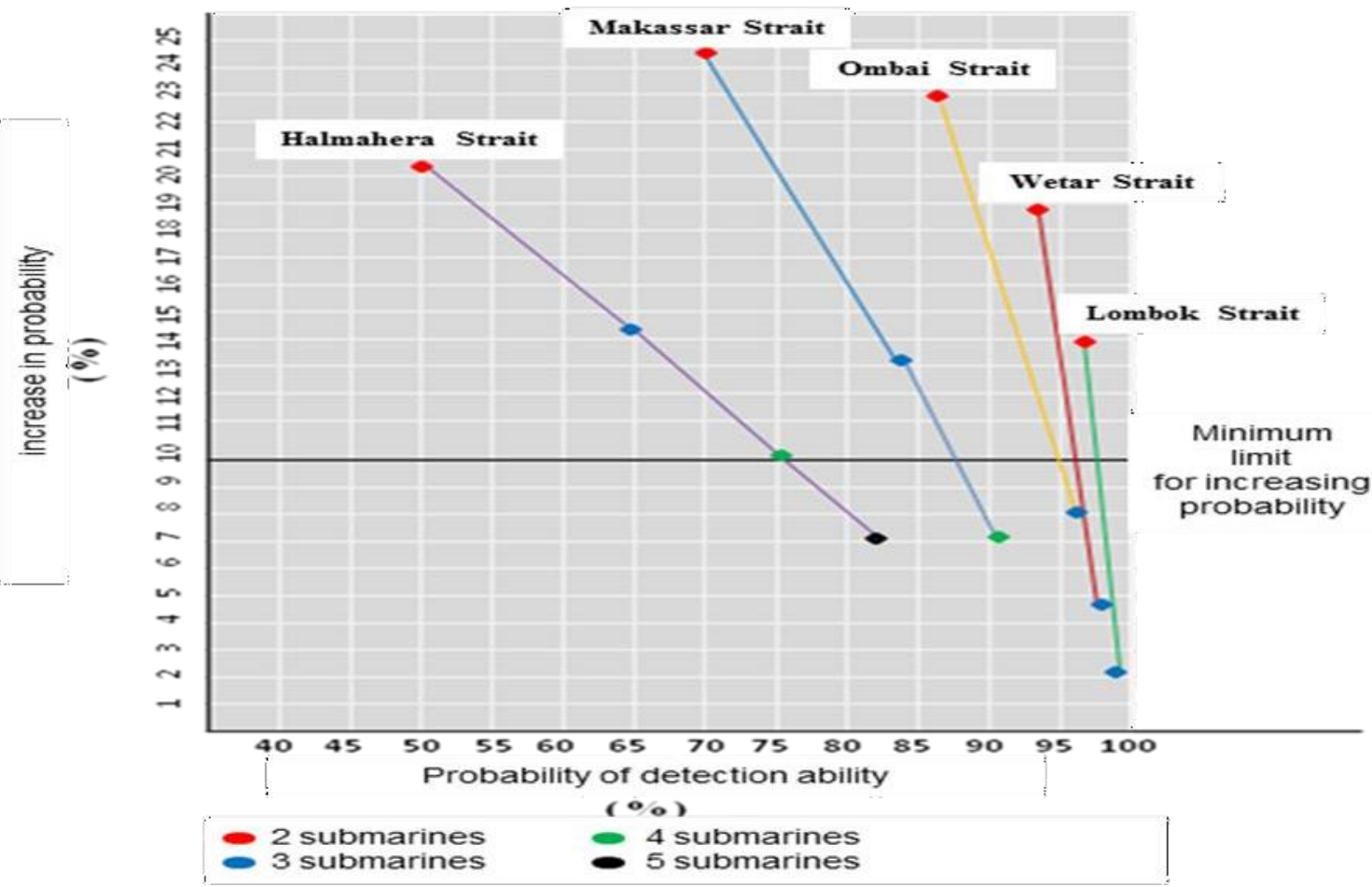

Fig.8 Probability Chart 
c. Determination of the Number of Submarines. After processing data, the number of submarines needed in each position using the patrol method are as follows:

1) Makassar Strait. With 4 Submarines the probability of detection ability is $91.3 \%$ but the increase in probability is not significant only $7.3 \%$ (less than 10\%). So for the Makassar Strait only 3 submarines are placed.

2) Lombok Strait. With 3 submarines, the probability of detection ability is $99.5 \%$. But the increase in probability is not significant only $2.4 \%$ (less than $10 \%$ ). So for the Lombok Strait only 2 submarines were placed.

3) Halmahera sea. With 5 submarines the probability of detection ability is $82.4 \%$ but the increase in probability is not significant only $7.3 \%$ (less than 10\%). So for the Halmahera Sea only 4 submarines are placed.

4) Wetar Strait. With 3 submarines the probability of detection ability is $98.3 \%$, but the probability increase is not significant, only $4.8 \%$ (less than 10\%). So for the Wetar Strait only 2 submarines are placed.

5) Ombai Strait. With 3 submarines the probability of detection ability is $95.2 \%$ but the increase in probability is not significant only $8.4 \%$ (less than 10\%). So for the Ombai Strait only 2 submarines are placed.

Then the total number of submarines needed to maintain Indonesia's strategic straits using the probability detection method approach in the patrol position is 13 submarines.

\section{CONCLUSION}

From the processing and data analysis above, conclusions can be drawn as follows: a. The total number of submarines needed to maintain Indonesia's strategic straits using the probability detection method approach in the patrol position amounted to 13 submarines.

b. Determination of the number of submarines is declared sufficient if the placement of a number of submarines in a particular area has a probability of detection of $90 \%$. If the probability of detection has not reached $90 \%$, an additional number of submarines is required, but if there is an addition of a submarine the probability of detection is less than $10 \%$ (not significant), then the addition of the submarine is no longer needed.

c. Determination of the number of submarines is needed to deal with threats with the highest level of classification where the threats come from:

1) Threats from the north enter through the Sulawesi Sea and the Halmahera Sea (Maluku Sea)

2) Threats from the south originate through the Lombok Strait, Ombai and Wetar.

\section{ACKNOWLEDGEMENTS}

The authors greatly acknowledge the support from Indonesian Naval Technology College STTAL and Koarmada II on this research work. The authors are also grateful to the anonymous reviewers and journaleditorial board for their many insightful comments, which have significantly improved this article.

\section{REFERENCES}

Ali, M. 2002. The Concept of Marine Submarine War Submarine Class 209/1300. Jakarta. Seskoal.

Hines, W.H. and Montgomery, D.C. 1990. Probability and Statistics in Engineering and Management. Jakarta. UI Press.

Donohue, H. 1994. Mines, Mining and mine countermeasure. New South Wales, Australian Defence Indistries Ltd. 
tchinson, R. 2001. Submarines war beneath the waves from 1776 to the present day. New York. Harper Collins Publisher.

Jackson, R. 2000. Submarines of the world. London. Brown Books.

Mabesal. 2001. The doctrine of the Indonesian Navy, Eka Sasana Jaya. Jakarta.

Mabesal. 1998. Technical Manual for Combat Use of Cakra Class Submarines. Jakarta.
Mabesal. 2006. Long-term Plan of Strength of the Indonesian Navy. Jakarta.

Space Magazine. 2004. Submarines: The Silent Warrior, XIII edition. Jakarta. PT Gramedia.

Wagner, D.H. 1999. Naval Operations Analysis, third edition. Annapolis. Naval Institute Press. 